\title{
KUALITAS KEFIR DENGAN PENAMBAHAN TEPUNG DAUN STEVIA (Stevia rebaudiana Bertoni) SEBAGAI PEMANIS ALAMI
}

\author{
The Quality of Kefir using Stevia (Stevia rebaudiana Bertoni) Leaf Flour \\ Addition as Natural Sweetener \\ Dwi Rumdaini Intan Permatasari ${ }^{1)}$, Purwadi ${ }^{2)}$, Herly Evanuarini ${ }^{2)}$ \\ 1) PT. Super Unggas Jaya, Cheil Jedang Jl. H.M Basuno Kelurahan Ploso Kec. Jati, Kudus Jawa Tengah \\ ${ }^{2)}$ Fakultas Peternakan, Universitas Brawijaya. Jl. Veteran, Malang, Jawa Timur, Indonesia, 65145 \\ Email : herlyfptub@ub.ac.id
}

Diterima 30 Agustus 2018; diterima pasca revisi 23 Oktober 2018

Layak diterbitkan 30 Oktober 2018

\begin{abstract}
Stevia is one of natural sweetener a substitute for sugar low calorie. Stevia widely used as many consumers want sweetening healthy. Stevia leaf powder was used to develop an kefir as sweetener replacer to sugar. The objective of this research was to determine the best percentage of using stevia leaf flour as substitution ingredient on kefir based on total sugar, acidity, total solids and sineresis of kefir. The materials research were fresh milk, kefir grain, and stevia leaf flour. The research method was using experimental design with four treatments and four replications. The treatments were P1 0.5\% stevia leaf flour, P2 $0.75 \%$ stevia leaf flour P3 $1 \%$ stevia leaf flour and P4 $1.25 \%$ stevia leaf flour. The data were analyzed by ANOVA and if there were significant effect then would be continued by Duncan's Multiple Range Test (DMRT). The result showed that substituting sugar using stevia leaf flour gave highly significant different effect $(P<0.01)$ on total sugar, acidity, total solids and sineresis kefir. It can be concluded that the kefir with the used $1.25 \%$ stevia leaf flour gave the best result with the total sugar was $6.82^{\circ}$ Brix, acidity was $0.55 \%$, total solids was $11.75 \%$, and sineresis was $23.75 \%$.
\end{abstract}

Keywords: Kefir; stevia leafflour; sineresis; sweetener 


\section{ABSTRAK}

Tepung daun stevia merupakan salah satu pemanis alami yang dapat digunakan sebagai pemanis rendah kalori. Stevia mulai banyak dikonsumsi oleh konsumen karena mereka menginginkan pemanis yang sehat. Tepung daun Stevia ditambahkan didalam kefir sebagai pemanis alami pengganti gula. Tujuan dari penelitian ini adalah untuk mengetahui persentase terbaik penambahan tepung daun stevia sebagai pemanis alami pada kefir ditinjau dari kadar gula, keasaman, total padatan dan sineresis kefir. Bahan dalam penelitian ini adalah susu segar, kefir grain, dan tepung daun stevia. Metode penelitian ini menggunakan metode percobaan laboratorium dengan empat perlakuan dan empat ulangan. Perlakuan P1 menggunakan 0,5\% tepung daun stevia, P2 0,75\% tepung daun stevia, P3 1\% tepung daun stevia dan P4 1,25\% tepung daun stevia. Data dianalisis menggunakan analisis ragam (ANOVA) dan jika terdapat perbedaan yang nyata maka dilanjutkan dengan Uji Jarak Berganda Duncan (UJBD). Hasil penelitian menunjukkan bahwa penambahan tepung daun stevia memberikan pengaruh yang sangat nyata $(P<0,01)$ terhadap kadar gula, keasaman, total padatan dan sineresis kefir. Penggunaan tepung daun stevia dengan persentase yang meningkat akan meningkatkan kadar gula, menurunkan keasaman, meningkatkan total padatan dan menurunkan sineresis. Dapat disimpulkan bahwa kefir dengan tepung daun stevia 1,25\% menghasilkan hasil terbaik dengan kadar gula 6,82 ${ }^{\circ}$ Brix, keasaman 0,55\%, total padatan 11,75\%, dan sineresisnya adalah $23,75 \%$.

Kata kunci: Kefir; tepung daun stevia; pemanis; sineresis

\section{PENDAHULUAN}

Kefir adalah produk yang dihasilkan dari fermentasi susu sapi, domba atau kambing yang telah dipasteurisasi menggunakan starter berupa butir atau biji kefir (kefir grain/kefir granule). Fermentasi merupakan suatu proses mengubah substansi kimia menjadi lebih sederhana dengan bantuan bakteri, kapang maupun khamir. Menurut Bahar (2008) kefir merupakan butiran-butiran putih atau krem yang mengandung kumpulan bakteri asam laktat seperti Lactobacili, Streptococcus sp. dan beberapa jenis ragi atau khamir non pathogen seperti Saccharomyces sp. dan Candida sp.

Di Indonesia, kefir mulai digemari oleh masyarakat sebagai minuman fungsional, karena khasiatnya telah dipercaya mampu mencegah dan mengobati berbagai penyakit seperti jantung, ginjal, paru-paru, hati, menurunkan kolesterol, meningkatkan nafsu makan, serta membuat tubuh menjadi segar dan bertenaga. Namun, kefir untuk konsumsi kurang diminati oleh masyarakat karena memiliki rasa yang asam. Apabila kefir ditambahkan dengan gula untuk mengurangi rasa asamnya, kefir tersebut tidak dapat dikonsumsi oleh penderita diabetes. Upaya untuk mengurangi rasa asam dari kefir dan dapat dikonsumsi oleh penderita diabetes dapat menggunakan pemanis alami, salah satu contohnya adalah tepung daun stevia.

Stevia rebaudiana Bertoni adalah suatu sumber bahan pemanis alami yang
*Corresponding author :

Herly Evanuarini

Email : herlyfptub@ub.ac.id

Fakultas Peternakan, Universitas Brawijaya. J1.

Veteran, Malang, Jawa Timur, Indonesia, 65145
How to cite :

Permatasari, D.R.I., Purwadi., \& Evanuarini, H. (2018). Kualitas Kefir dengan Penambahan Tepung Daun Stevia (Stevia rebaudiana Bertoni) Sebagai Pemanis Alami. Jurnal Ilmu dan Teknologi Hasil Ternak, 13 (2), 91-97 
mempunyai tingkat kemanisan 200-300 kali lebih manis dari pada gula tebu (Ratnani \& Anggraeni, 2005). Stevia dapat memberikan jalan keluar bagi konsumen yang tidak bisa atau tidak boleh mengkonsumsi gula pasir / gula tebu, misalnya penderita diabetes, karena tentu saja gula stevia lebih aman dibandingkan pemanis sintetis atau buatan.

Rasa manis ini dihasilkan dari daun tanaman stevia yang disebabkan adanya kandungan glikosida dalam daun stevia tersebut. Glikosida ini merupakan suatu senyawa yang terdiri dari gula dan bukan gula (aglukon). Stevioside adalah pemanis yang berbentuk serbuk putih halus dan berintensitas tinggi, yang diisolasi dari dan dimurnikan dari daun tanaman stevia (Widodo, dkk., 2015).

Bubuk daun stevia diperoleh dari tanaman, sehingga penggunaannya lebih aman, non karsinogenik dan non kalori. Keunggulan dari stevia adalah tidak menyebabkan carries pada gigi, berkadar kalori rendah dan cocok bagi penderita diabetes, serta aman pada pemakaian jangka panjang (Buchori, 2007).

Pemanis stevia lebih stabil dan tidak rusak pada suhu tinggi seperti sakarin atau aspartam (Raini dan Isnawati, 2011), bersifat non toksis, dapat mencegah hiperglismia, merangsang produksi insulin (Astuti dan Agustia, 2012) dan mempunyai efek sebagai antimikroba (Latifah, dkk., 2015).

Penambahan tepung daun stevia sebagai pemanis yang ditambahkan pada kefir dengan persentase yang tepat bertujuan untuk meningkatkan kualitas kefir ditinjau dari kadar gula, keasaman, total padatan dan sineresis kefir.

\section{MATERI DAN METODE}

Materi penelitian yang digunakan adalah kefir dengan penambahan tepung daun stevia sebagai pemanis. Bahan baku yang digunakan berupa susu sapi segar yang diperoleh dari peternak di daerah Junrejo, kefir grain di peroleh dari Divisi
Mikrobiologi, Laboratorium Teknologi Hasil Ternak, Fakultas Peternakan, Universitas Brawijaya. Tepung stevia didapatkan dari merk dagang komersial. Tepung daun stevia berasal dari produk PT. Health Paradise Selangor Malaysia dengan merk dagang Organic Green Leaf Stevia.

Peralatan yang digunakan untuk membuat kefir diantaranya: timbangan analitik, refrigerator (LG), panci pasteurisasi, kompor gas, cup, sendok, toples tertutup, sterofoam dan spatula. Peralatan untuk analisis diantaranya timbangan analitik, cawan petri, oven, eksikator, refraktometer, pipet tetes, buret, erlenmeyer, dan beaker glass.

Metode penelitian yang digunakan adalah percobaan laboratorium dengan menggunakan Rancangan Acak Lengkap (RAL) dengan 4 perlakuan dan 4 ulangan. Perlakuan yang dilakukan diantaranya:

P1 : Kefir + tepung daun stevia $0,5 \%$

$\mathrm{P} 2$ : Kefir + tepung daun stevia $0,75 \%$

P3 : Kefir + tepung daun stevia $1 \%$

$\mathrm{P} 4$ : Kefir + tepung daun stevia $1,25 \%$

Prosedur pembuatan kefir dengan penambahan tepung daun stevia modifikasi menurut Evanuarini (2015) sebagai berikut:

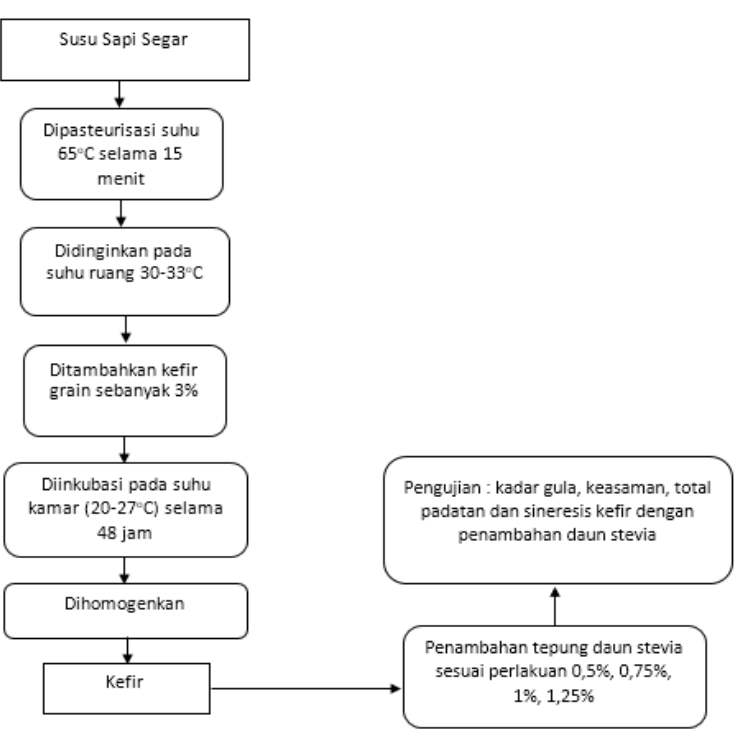




\section{Variabel Penelitian}

Variabel yang diamati adalah pengujian total padatan menggunakan oven (AOAC, 2005), pengujian sineresis menggunakan sentrifuge (AOAC, 2005), pengujian kadar gula menggunakan refraktometer (AOAC, 2005), dan pengujian keasaman menggunakan buret (AOAC, 2005).

\section{Analisis Data}

Data hasil penelitian dianalisis secara statistik menggunakan analisis ragam (ANOVA). Apabila diperoleh hasil yang berbeda atau signifikan maka dilanjutkan dengan Uji Jarak Berganda Duncan (UJBD).

\section{HASIL DAN PEMBAHASAN}

\section{Nilai Kadar Gula Kefir dengan Penambahan Tepung Daun Stevia}

Hasil analisis ragam menunjukkan bahwa penambahan tepung daun stevia pada kefir dengan persentase yang berbeda memberikan pengaruh yang sangat nyata $(\mathrm{P}<0,01)$ terhadap kadar gula kefir. Nilai rataan kadar gula kefir dengan penambahan tepung daun stevia dapat dilihat pad Tabel 1.

Tabel 1. Nilai Rataan Total Kadar Gula Kefir dengan Penambahan Tepung Daun Stevia

\begin{tabular}{cc}
\hline Perlakuan & Kadar gula $\left({ }^{\circ}\right.$ Brix $)$ \\
\hline P1 & $4,52 \pm 0,60^{\mathrm{a}}$ \\
P2 & $5,75 \pm 0,28^{\mathrm{a}}$ \\
P3 & $6,30 \pm 0,08^{\mathrm{b}}$ \\
P4 & $6,82 \pm 0,12^{\mathrm{c}}$ \\
\hline
\end{tabular}

Keterangan : ${ }^{\text {a, b, c, d }}$ Superskrip yang berbeda pada kolom yang sama menunjukkan perbedaan yang sangat nyata $(\mathrm{P}<0,01)$

Tabel 1 nilai rataan total kadar gula kefir dengan penambahan tepung daun stevia antara $4,52^{\circ}$ Brix $-6,82^{\circ}$ Brix. Nilai total kadar gula tertinggi diperoleh pada P4 dengan penambahan $1,25 \%$ tepung daun stevia, sedangkan nilai terendah diperoleh dari P1 dengan penambahan
$0,5 \%$ tepung daun stevia. Perlakuan P4 mengandung kadar gula tertinggi, hal ini diduga disebabkan oleh penambahan tepung daun stevia paling banyak. Daun stevia mengandung glikosida yang di dalamnya mengandung komponen utama steviosida yang dapat menghasilkan rasa manis dengan tingkat kemanisan 200-300 kali lebih tinggi dibandingkan gula tebu atau sukrosa (Mayanningtyas, 2016). Menurut Ratnani \& Anggraeni (2005) rasa manis ini dihasilkan dari daun tanaman stevia tersebut yang disebabkan adanya kandungan glikosida dalam daun stevia tersebut.

Glikosida ini merupakan suatu senyawa yang terdiri dari gula dan bukan gula (aglukon). Bila gulanya itu glukosa maka glikosida tersebut disebut Glukoside. Berdasarkan tabel nutrition fact yang ada pada kemasan kadar gula tepung daun stevia berkisar 74,6 g/100 g tepung daun stevia. Menurut Goyal, Samsher dan Goyal (2010) tingkat kemanisan 1 sendok teh gula setara dengan 1/9 tepung daun stevia, sehingga $1 \mathrm{~g}$ gula setara dengan $0,125 \mathrm{~g}$ tepung daun stevia.

\section{Nilai Keasaman Kefir dengan Penambahan Tepung Daun Stevia}

Hasil analisis ragam menunjukkan bahwa penambahan tepung daun stevia pada kefir dengan persentase yang berbeda memberikan pengaruh yang sangat nyata $(\mathrm{P}<0,01)$ terhadap keasaman kefir. Nilai rataan keasaman kefir dengan penambahan tepung daun stevia dapat dilihat pad Tabel 2.

Tabel 2 nilai rataan keasaman kefir berkisar antara 0,65\%-0,55\%. Nilai rataan keasaman tertinggi diperoleh dari perlakuan P1 dengan penambahan tepung daun stevia sebesar $0,5 \%$, sedangkan nilai rataan keasaman terendah diperoleh dari perlakuan $\mathrm{P} 4$ dengan penambahan tepung daun stevia $1,25 \%$. Hal ini dikarenakan penambahan tepung daun stevia sebagai pemanis akan menghambat aktivitas bakteri sehingga keasamannya akan menurun. Hal ini sesuai dengan pendapat 
dari Evanuarini (2015) yang menyebutkan bahwa semakin banyak pemberian gula maka cenderung meningkatkan $\mathrm{pH}$ dan menurunkan keasaman susu fermentasi.

Tabel 2. Nilai Rataan Keasaman Kefir dengan Penambahan Tepung Daun Stevia

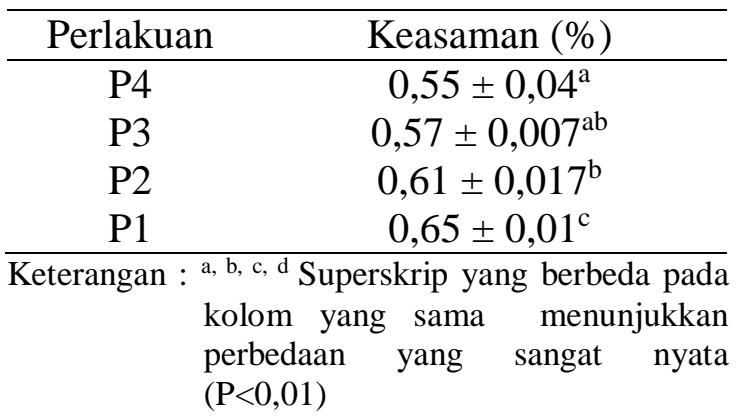

Semakin tinggi kadar pemberian gula maka akan menyebabkan penurunan aktivitas bakteri starter sehingga pembentukan asam laktat dari laktosa juga semakin menurun. Jika bakteri, khamir dan kapang ditempatkan dalam larutan gula yang pekat, maka air dalam sel akan keluar menembus membran dan mengalir ke dalam larutan gula, peristiwa tersebut dikenal dengan osmosis, dan dalam keadaan ini sel mikroorganisme mengalami plasmolisis sehingga perkembangbiakannya terhambat.

\section{Nilai Total Padatan Kefir dengan Penambahan Tepung Daun Stevia}

Hasil analisis ragam menunjukkan bahwa penambahan tepung daun stevia pada kefir dengan persentase yang berbeda memberikan pengaruh yang sangat nyata $(\mathrm{P}<0,01)$ terhadap total padatan kefir. Nilai rataan total padatan kefir dengan penambahan tepung daun stevia dapat dilihat pada Tabel 3. nilai rataan total padatan kefir dengan penambahan tepung daun stevia berkisar antara 8,91\%$11,75 \%$. Nilai rataan total padatan tertinggi diperoleh pada $\mathrm{P} 4$ dengan penambahan tepung daun stevia sebesar 1,25\%, sedangkan nilai rataan total padatan terendah diperoleh dari perlakuan P1 dengan penambahan tepung daun stevia sebesar $0,5 \%$.
Tabel 3. Nilai Rataan Total Padatan Kefir dengan Penambahan Tepung Daun Stevia

\begin{tabular}{cc}
\hline Perlakuan & Total Padatan $(\%)$ \\
\hline P1 & $8,91 \pm 0,17^{\mathrm{a}}$ \\
P2 & $9,35 \pm 0,47^{\mathrm{a}}$ \\
P3 & $11,00 \pm 0,26^{\mathrm{b}}$ \\
P4 & $11,75 \pm 0,31^{\mathrm{c}}$ \\
\hline Keterangan : a, b, c Superskrip yang berbeda pada \\
kolom yang sama menunjukkan \\
perbedaan yang sangat nyata \\
$(\mathrm{P}<0,01)$
\end{tabular}

Kandungan serat dalam tepung daun stevia dapat meningkatkan kandungan total padatan kefir serta bersifat mengikat air sehingga semakin banyak penambahan tepung daun stevia maka akan semakin banyak jumlah air yang terikat sehingga menyebabkan kadar air menurun dan akhirnya kefir akan semakin kental. (Meikapasa dan Seventilofa, 2016) menyatakan bahwa gula memiliki sifat higroskopis sehingga mudah larut dalam air, adanya campuran pelarut air menyebabkan peluang kelarutan gula semakin meningkat.

Peningkatan total padatan terlarut disebabkan karena terjadinya pemutusan rantai panjang senyawa-senyawa karbohidrat menjadi senyawa gula yang larut. Peningkatan TPT yang sejalan dengan peningkatan suhu dan waktu pemasakan ini disebabkan karena semakin tinggi suhu menyebabkan pemutusan rantai-rantai panjang senyawa karbohidrat menjadi senyawa gula yang larut menjadi semakin cepat, sehingga kandungan gula yang terdapat dalam adonan akan semakin banyak larut.

\section{Nilai Sineresis Kefir dengan Penambahan Tepung Daun Stevia}

Hasil analisis ragam menunjukkan bahwa penambahan tepung daun stevia pada kefir dengan persentase yang berbeda memberikan pengaruh yang sangat nyata $(\mathrm{P}<0,01)$ terhadap sineresis kefir. Nilai rataan sineresis kefir dengan penambahan tepung daun stevia dapat dilihat pada Tabel 4. 
Tabel 4. Nilai Rataan Sineresis Kefir dengan Penambahan Tepung Daun Stevia

\begin{tabular}{cc}
\hline Perlakuan & Sineresis $(\%)$ \\
\hline P4 & $23,75 \pm 0,52^{\mathrm{a}}$ \\
$\mathrm{P} 3$ & $25,75 \pm 0,45^{\mathrm{b}}$ \\
$\mathrm{P} 2$ & $26,85 \pm 0,28^{\mathrm{c}}$ \\
$\mathrm{P} 1$ & $27,65 \pm 0,47^{\mathrm{d}}$ \\
\hline Keterangan : a, b, c, d Superskrip yang berbeda pada \\
kolom yang sama menunjukkan \\
perbedaan yang sangat nyata \\
$(\mathrm{P}<0,01)$
\end{tabular}

Tabel 4 nilai rataan sineresis kefir berkisar antara $27,65 \%$ - 23,75\%. Nilai rataan sineresis tertinggi diperoleh dari perlakuan P1 dengan penambahan tepung daun stevia $0,5 \%$, sedangkan nilai rataan sineresis terendah diperoleh dari perlakuan P4 dengan penambahan tepung daun stevia sebesar $1,25 \%$. Sineresis kefir dengan penambahan tepung daun stevia mempunyai kecenderungan semakin menurun.

Semakin tinggi penambahan tepung daun stevia maka semakin rendah sineresis kefir. Semakin turunnya sineresis kefir dengan meningkatnya perlakuan diduga karena jumah padatan yang semakin tinggi akibat penambahan tepung daun stevia. Menurut Dibyanti, dkk (2014) faktorfaktor yang mempengaruhi sineresis kefir antara lain adalah keasaman dan $\mathrm{pH}$, total padatan serta daya ikat air. Penambahan tepung daun stevia yang semakin meningkat, maka kandungan total padatan yang ada didalam kefir akan meningkat dan sineresis akan turun. Hal ini disebabkan karena tepung daun stevia mengandung amilopektin yang mampu menyerap air. Tamime (2006) menambahkan bahwa sineresis terjadi akibat dari protein terkoagulasi dan menurunnya daya ikat air, gelatin yang membentuk ikatan peptida dengan kasein dan mencegah terjadinya ikatan hidrogen antara kasein yang bermuatan negatif dan asam laktat yang bermuatan positif yang terjadi pada suasana asam. Sumardikan (2007) menyatakan bahwa bakteri asam laktat akan merombak laktosa menjadi asam laktat, sehingga menurunkan nilai pH kefir. Keadaan asam pada kefir membuat air yang berikatan dengan protein terlepas dan menimbulkan terjadinya sineresis.

\section{KESIMPULAN}

Berdasarkan hasil penelitian dapat disimpulkan bahwa penambahan $1,25 \%$ tepung daun stevia pada kefir menghasilkan kefir dengan kualitas terbaik dengan rataan nilai total padatan $11,75 \%$, sineresis $23,75 \%$, keasaman $0,55 \%$ dan kadar gula $6,82^{\circ}$ Brix

\section{DAFTAR PUSTAKA}

Astuti, S. D., \& Agustia, F. C. (2012). Optimasi formula \& karakterisasi cookies fungsional berbasis kacang merah \& kedelai organik dengan penambahan gula stevia \& kappa karagenan.

Bahar, B. (2008). Kefir Minuman Fermentasi degan Segudang Khasiat untuk Kesehatan. Jakarta: PT. Gramedia Pustaka Utama.

Buchori, L. (2007). Pembuatan gula non karsinogenik non kalori dari daun stevia. Reaktor, 11(2), 57. https://doi.org/10.14710/reaktor.11.2.57-60

Dibyanti, P., Radiati, L. E., \& Rosyidi, D. (2014). Effect of Addition of Various Concentrations of Culture \& Incubation Period on $\mathrm{pH}$, Acidity Levels, Viscosity \& Syneresis Set Yoghurt. Jurnal Ilmu Ternak, 1-6.

Evanuarini, H. (2010). Pengaruh suhu \& lama pemeraman pada inkubator terhadap kualitas fisik kefir. Jurnal Ilmu-Ilmu Peternakan, 20(2), 8-13.

Goyal, S. K., Samsher, \& Goyal, R. K. (2010). Stevia ( Stevia rebaudiana) a bio-sweetener: a review. 
International Journal of Food Sciences \& Nutrition, 61(1), 1-10. https://doi.org/10.3109/09637480903193049

Kumalasari, K. E. D., Legowo, A. M., \& Al-Baarri, A. N. (2013). Total bakteri asam laktat, kadar laktosa, ph, keasaman, kesukaan drink yogurt dengan penambahan ekstrak buah kelengkeng. Jurnal Aplikasi Teknologi Pangan, 2(4), 165-168.

Latifah, A. T. W., Hidayati, N., Sofyan, A., Fuadi, A. M., \& Harismah, K. (2015). Preparation of Modified Jelly By Using Sweet Potato \& Stevia (Stevia Rebaudiana Bertoni) As Non Calorie Sweetener. University Research Colloquium.

Lindawati, S. A., Sriyani, N. L. P., Hartawan, M., \& Suranjaya, I. G. (1970). Study mikrobiologis kefir dengan waktu simpan berbeda. Majalah Ilmiah Peternakan, 18(3), 95-99. https://doi.org/10.24843/MIP.2015.v18.i03.p03

Mayanningtyas, Y. (2017). Pengaruh Substitusi Tepung Daun Stevia (Stevia Rebaudiana) Terhadap Kadar Gula Reduksi\&Tingkat Kekerasan Biskuit Ubi Jalar Ungu(Ipomoea batatas L.). Surakarta: Universitas Muhammadiyah Surakarta.

Meikapasa, N. W. P., \& Seventilofa, I. G. N. O. (2016). Karakteristik total padatan terlarut (TPT), stabilitas likopen \& vitamin c saus tomat pada berbagai kombinasi suhu dan waktu pemasakan. GaneÇ Swara, 10(1), 81-86.

Raini, M., \& Isnawati, A. (2011). Kajian: khasiat \& keamanan stevia sebagai pemanis pengganti gula. Media Penelitian dan Pengembangan Kesehatan, 21(4), 145 - 156.

Ratnani, R. D., \& Anggraeni, R. (2005). Ekstraksi gula stevia dari tanaman stevia rebaudiana bertoni. momentum, 1(2), 27-32.

Sumardikan. (2007). Carboxymethylcellulose (CMC) terhadap pH, Keasaman, Viskositas, Sineresis dan Mutu Organoleptik. Teknologi Peternakan.

Tamine, Y. (2006). Yoghurt: Science \& Technology (2nd ed.). Germany: Woodhead Publishing Limited \& CRC Press LLC.

Widodo, W., Munawaroh, N., \& Indratiningsih, I. (2015). Produksi low calorie sweet bio-yoghurt dengan penambahan ekstrak daun stevia (stevia rebaudiana) sebagai pengganti gula. Jurnal Agritech, 35(04), 464-473. https://doi.org/10.22146/agritech.9331 